\title{
Pengaruh Model Guided Inquiry Learning terhadap Hasil Belajar Siswa di SMAN 1 Pringgarata
}

\author{
${ }^{1}$ Mahzin Ali Akbar, ${ }^{1 *}$ H. Hikmawati, ${ }^{1}$ Joni Rokhmat \\ 1Program Studi Pendidikan Fisika, FKIP Universitas Mataram, Jl. Majapahit No. 62 Mataram, \\ Indonesia 83115, Indonesia \\ *Corresponding Author e-mail: hikmawati@unram.ac.id
}

Received: October 2019; Revised: May 2020; Published: July 2020

\begin{abstract}
Abstrak
Tujuan penelitian ini adalah mengetahui pengaruh model Guided Inquiry Learning terhadap hasil belajar siswa SMA di SMAN 1 Pringgarata. Jenis penelitian yang digunakan adalah penelitian eksperimen semu dengan desain penelitian yaitu pretest-postest control group design. Teknik cluster random sampling digunakan untuk menentukan sampel peneltian di mana, kelas X IPA 3 sebagai kelas eksperimen (21 siswa) yang dibelajarkan menggunakan model Guided Inquiry Learning dan kelas X IPA 2 sebagai kelas kontrol (20 siswa) yang dibelajarkan menggunakan pembelajaran langsung. Instrumen tes berupa pilihan ganda sebanyak 30 item soal digunakan untuk mengukur hasil belajar siswa yang diberikan sebelum dan sesudah pembelajaran. Hasil penelitian menunjukkan bahwa nilai rata-rata pretest kelas eksperimen sebesar 30,10 dan kelas kontrol sebesar 33,20 sedangkan nilai ratarata post-test kelas eksperimen sebesar 80,57 dan kelas kontrol sebesar 75,60. Hasil uji statistik menggunakan uji-t dengan taraf signifikan $5 \%$, diperoleh hasil t-hitung sebesar $(4,12)>t$-tabel sebesar $(2,02)$, sehingga $\mathrm{H}_{0}$ ditolak. Berdasarkan hasil penelitian, dapat disimpulkan bahwa model Guided Inquiry Learning berpengaruh terhadap hasil belajar siswa SMA di SMAN 1 Pringgarata.
\end{abstract}

Kata Kunci: Guided Inquiry Learning, Hasil Belajar

\section{The Effect of Guided Inquiry Learning Model on Student Learning Outcomes at SMAN 1 Pringgarata}

\begin{abstract}
The purpose of this study was to determine the effect of the Guided Inquiry Learning model on high school students' learning outcomes at SMAN 1 Pringgarata. The quasi-experimental research with pretest-posttest control group design was used on this study. The cluster random sampling technique was used to determine the research sample in which, Class XIPA 3 as an experimental class (21 students) were taught using the Guided Inquiry Learning model and Class X IPA 2 as a control class (20 students) that were learned using direct learning. The 30-item multiple choice test instrument was used to measure student learning outcomes given before and after learning. The results showed that the average value of the experimental class pretest was 30.10 and the control class was 33.20 while the post-test mean value of the experimental class was 80.57 and the control class was 75.60. The results of statistical tests using the $t$-test with a significance level of $5 \%$, the results obtained $t$ test of (4.12)> t-table of (2.02), so that $\mathrm{HO}$ is rejected. Based on the results of the study, it can be concluded that the Guided Inquiry Learning model effect on high school students' learning outcomes at SMAN 1 Pringgarata. Keywords: Guided Inquiry Learning, Learning Outcomes
\end{abstract}

How to Cite: Akbar, M., Hikmawati, H., \& Rokhmat, J. (2020). Pengaruh Model Guided Inquiry Learning terhadap Hasil Belajar Siswa di SMAN 1 Pringgarata. Jurnal Penelitian dan Pengkajian Ilmu Pendidikan: e-Saintika, 4(2), 105-111. doi:https://doi.org/10.36312/e-saintika.v4i2.142 


\section{PENDAHULUAN}

Ilmu Fisika adalah ilmu yang lahir dan berkembang melalui langkah-langkah ilmiah yaitu kegiatan pengamatan, membuat pertanyaan, merumuskan hipotesis, pengujian hipotesis melalui eksperimen, penarikan kesimpulan, serta penemuan teori, dan konsep. Dengan demikian Hakikat fisika merupakan ilmu pengetahuan yang mempelajari tentang gejala-gejala atau fenomena alam melalui serangkaian proses ilmiah yang dibangan atas dasar sikap ilmiah dan hasilnya terwujud sebagai produk ilmiah berupa konsep, prinsip, dan teori yang berlaku secara universal (Trianto, 2010). Peranan fisika sangat penting dalam pembelajaran sehingga perlu ditingkatkan pengetahuan tentang prinsip-prinsip maupun konsep-konsep yang terdapat dalam fisika. Di samping itu, siswa juga mampu menerapkan pengetahuan mengenai fisika dalam kehidupan sehari-hari diantaranya melalui kegiatan pembelajaran di sekolah. Pengelolaan kegiatan pembelajaran perlu dilakukan dengan baik dengan tujuan agar siswa dapat memahami konsep fisika serta mempunyai keterampilan dalam memecahkan masalah, sehingga dapat memberikan hasil belajar yang baik.

Berdasarkan informasi yang diperoleh peneliti melalui wawancara dengan guru fisika di SMAN 1 Pringgarata, hasil belajar siswa kelas $X$ masih belum optimal. Banyak siswa belum mencapai Kriteria Ketuntasan Minimum (KKM) yang ditetapkan oleh sekolah yaitu 75. Hal ini dapat dilihat dari nilai rata-rata ulangan mata pelajaran fisika kelas X SMAN 1 Pringgarata Tahun Ajaran 2017/2018 seperti ditunjukkan pada Tabel 1.

Tabel 1 Nilai Rata-rata Ulangan Harian Mata Pelajaran Fisika SMAN 1 Pringgarata

\begin{tabular}{lllll}
\hline No & Kelas & Nilai & KKM & Keterangan \\
\hline 1 & X IPA 1 & 45 & 75 & TidakTuntas \\
2 & X IPA 2 & 25 & 75 & Tidak Tuntas \\
3 & X IPA 3 & 42 & 75 & Tidak Tuntas \\
\hline
\end{tabular}

(Arsip Guru Mata Pelajaran Fisika, 2018/2019)

Berdasarkan hasil observasi peneliti di Kelas X SMAN 1 Pringgarata masih banyak ditemukan peserta didik kurang aktif yang pada akhirnya pembelajaran di kelas menjadi pembelajaran yang berpusat pada guru (teacher centered). Pembelajaran teacher centered ini merupakan pembelajaran dimana guru lebih mendominasi proses kegiatan pembelajaran sehingga guru menjadi pusat informasi dan kurang melibatkan siswa secara aktif mencari dan menemukan informasi sendiri sehingga siswa cenderung bosan dan mengantuk di dalam kelas. Fakta inilah yang menjadi salah satu penyebab kurangnya keaktifan dan minat belajar siswa, sehingga dapat menyebabkan lemahnya siswa dalam menguasai konsep-konsep serta tidak memiliki keterampilan proses.

Hayati, dkk. (2017) menemukan bahwa terdapat pengaruh model pembelajaran inkuiri terhadap hasil belajar fisika siswa di SMA. Nilai rata-rata tes hasil belajar fisika pada kelas eksperimen yang menggunakan model pembelajaran inkuiri lebih tinggi dibandingkan dengan kelas kontrol yang menggunakan model pembelajaran konvensional. Susilawati, et.al (2015) menyatakan bahwa siswa yang mendapatkan pembelajaran dengan model pembelajaran inkuiri terbimbing secara keseluruhan memperoleh keterampilan proses sains yang lebih baik bila dibandingkan dengan siswa yang mendapatkan pembelajaran konvensional. Wahyuni dkk (2016) juga berpendapat bahwa terdapat pengaruh model pembelajaran inkuiri terbimbing 
dengan metode eksperimen terhadap hasil belajar fisika siswa SMA. Nilai rata-rata tes hasil belajar fisika pada kelas eksperimen yang menggunakan model pembelajaran inkuiri terbimbing lebih tinggi dibandingkan pada kelas kontrol yang menggunakan model pembelajaran konvensional.

Salah satu upaya untuk mengatasi permasalahan di atas yaitu inovasi pada model pembelajaran agar siswa memiliki keterampilan dalam memecahkan permasalahan yang ada dalam ilmu fisika. Model pembelajaran yang dimaksud adalah model Guided Inquiry Learning (pembelajaran inkuiri terbimbing). Menurut Gulo (dalam Trianto, 2007) menyatakan bahwa model ini merupakan rangkaian kegiatan pembelajaran yang melibatkan secara maksimal seluruh kemampuan siswa untuk mencari dan menyelidiki secara sistematis, kritis, logis, analitis, sehingga siswa dapat merumuskan sendiri penemuannya dengan penuh percaya diri. Anam (2015) mengatakan bahwa pada model ini setiap siswa didorong untuk terlibat aktif dalam proses belajar mengajar, salah satunya dengan secara aktif mengajukan pertanyaan yang baik terhadap setiap materi yang disampaikan dan pertanyaan tersebut tidak harus selalu dijawab oleh guru, karena semua siswa memiliki kesempatan yang sama untuk memberikan jawaban atas pertanyaan yang diajukan.

Kelebihan model Guided Inquiry Learning (GIL) menurut Shoimin (2016) yaitu: pertama, GIL merupakan strategi pembelajaran yang menekankan kepada pengembangan aspek kognitif, afektif, dan psikomotor secara seimbang sehingga pembelajaran dengan strategi ini dianggap lebih bermakna; kedua, GIL dapat memberikan ruang kepada siswa untuk belajar sesuai dengan gaya belajanya; ketiga, GIL merupakan strategi yang dianggap sesuai dengan perkembangan psikologi belajar modern yang menganggap belajar adalah proses perubahan tingkah laku berkat adanya pengalaman; keempat, GIL dapat melayani kebutuhan siswa yang memiliki kemampuan di atas rata-rata. Tujuan penelitian ini adalah mendeskripsikan pengaruh model Guided Inquiry Learning (GIL) terhadap hasil belajar siswa di SMAN 1 Pringgarata.

\section{METODE}

Jenis penelitian yang digunakan adalah penelitian eksperimen, yaitu metode yang dipakai untuk mencari pengaruh perilaku tertentu terhadap yang lain dalam kondisi yang terkendali (Sugiyono, 2013). Penelitian eksperimen ini menggunakan satu kelas eksperimen dan satu kelas kontrol. Desain penelitian yang digunakan adalah Pretest-Posttest Control group Design. Tempat Penelitian di SMAN 1 Pringgarata Lombok Tengah. Populasi penelitian ini seluruh siswa kelas X IPA SMAN 1 Pringgarata dengan jumlah 64 siswa, tehnik pengambilan sampel menggunakan cluster random sampling dan diperoleh kelas X IPA 3 sebagai kelas eksperimen sebanyak 21 siswa dan kelas X IPA 2 sebagai kelas Kontrol sebanyak 20 siswa.

Instrumen tes berbentuk pilihan ganda sebanyak 30 item soal digunakan untuk mengukur tes hasil belajar. Instrumen tersebut terlebih dahulu diuji validitas (kesahihan), reliabel (dapat dipercaya), tingkat kesukaran dan daya beda soal (Arikunto, 2013). Berdasarkan hasil uji coba instrumen, diperoleh sebanyak 31 soal valid dan 9 soal tidak valid dari 40 soal yang diujikan. Hasil uji reliabilitas yang diperoleh yaitu $r_{11}$ sebesar 0,7671 sedangkan $r_{\text {tabel }}$ sebesar 0,325. Berdasarkan hasil perhitungan terlihat bahwa $\mathrm{r}_{11}>\mathrm{r}_{\text {tabel, }}$, sehingga 31 soal tersebut dikatakan reliabel. Berdasarkan hasil perhitungan uji tingkat kesukaran soal dari 40 butir soal yang diujikan didapatkan 3 soal dengan kategori mudah, 15 soal dengan kategori sedang 
dan 22 soal dengan kategori sukar. Hasil uji daya beda soal dari 40 soal yang diujikan, diperoleh 6 soal dengan kategori baik, 7 soal dengan kategori cukup, 20 soal dengan kategori jelek dan 7 soal negatif.

Data yang telah diperoleh dari pemberian tes selanjutnya dianalisis dengan menggunakan uji homogenitas dan uji normalitas. Uji homogenitas postest bertujuan untuk menentukan tindak lanjut uji beda (uji-t) yang akan digunakan (Ridwan, 2013). Uji normalitas data bertujuan untuk mengetahui apakah data tes akhir terdistribusi normal atau tidak. Uji homogenitas menggunakan rumus F, sedangkan Uji normalitas dicari dengan menggunakan rumus Chi-kuadrat (Sugiyono, 2012). Setelah semua perlakuan berakhir kemudian peserta didik diberikan tes (post test). Statistik parametris yang digunakan untuk menguji hipotesis dua sampel dimana datanya berbentuk interval atau ratio dengan menggunakan $t$-test. Hipotesis dalam penelitian ini adalah sebagai berikut.

Ho : Tidak ada pengaruh model guided inquiry learning terhadap hasil belajar siswa.

Ha : Ada pengaruh model guided inquiry learning terhadap hasil belajar siswa.

Kriteria pengujian hipotesis yaitu:

a. Jika $t_{\text {hitung }} \leq t_{\text {tabel }}$, maka $H_{0}$ diterima dan $H_{a}$ ditolak

b. Jika $t_{\text {hitung }}>t_{\text {tabel }}$, maka $H_{0}$ ditolak dan $H_{a}$ diterima.

\section{HASIL DAN PEMBAHASAN}

Berdasarkan hasil penelitian yang didapatkan, besar nilai rata-rata tes awal hasil belajar fisika siswa pada kelas eksperimen adalah 30,10 sedangkan nilai rata-rata tes awal kelas kontrol adalah sebesar 33,20. Nilai tes akhir hasil belajar fisika siswa pada kelas eksperimen dan kelas kontrol didapatkan nilai rata-rata berturut-turut sebesar 80,57 dan 75,6. Data hasil tes awal dan tes akhir dari hasil belajar fisika untuk kelas eksperimen dan kelas kontrol dapat dilihat pada Tabel 2 berikut.

Tabel 2. Hasil Tes Awal dan Tes Akhir Sampel

\begin{tabular}{lllll}
\hline \multirow{2}{*}{ Komponen } & \multicolumn{2}{c}{ Tes Awal } & \multicolumn{2}{c}{ Tes Akhir } \\
\cline { 2 - 5 } & Eksperimen & Kontrol & Eksperimen & Kontrol \\
\hline Jumlah Siswa & 21 & 20 & 21 & 20 \\
Skor Tertinggi & 44 & 48 & 96 & 88 \\
Skor Terendah & 16 & 20 & 68 & 64 \\
Rata-rata & 30,10 & 33,20 & 80,57 & 75,60 \\
\hline
\end{tabular}

Berdasarkan Tabel 2 terlihat bahwa terdapat peningkatan hasil belajar fisika siswa pada kelas eksperimen dan kelas kontrol. Hal ini ditandai dengan adanya kenaikan nilai rata-rata peserta didik setelah diberi perlakuan. Untuk kelas ekperimen mengalami kenaikan sebesar 50,47 sedangkan untuk kelas kontrol mengalami peningkatan sebesar 42,40.

Berdasarkan hasil uji homogenitas dan normalitas data tes akhir, diperoleh data kedua kelas homogen dan terdistribusi normal. Nilai $F_{\text {hitung }}$ lebih kecil dibandingkan dengan $\mathrm{F}_{\text {tabel, }}$ atau 1,29 2,15 dengan $\mathrm{db}_{\text {pembilang }}=20$ dan $\mathrm{db}_{\text {penyebut }}=19$ pada taraf signifikasi 5\%. Dari keterangan tersebut dapat disimpulkan bahwa kedua sampel homogen dengan taraf signifikansi 5\%. Hasil perhitungan uji normalitas data hasil belajar fisika pada kedua kelas pada taraf signifikasi $5 \%$, diperoleh $\chi^{2}{ }_{\text {hitung }}$ kelas 
eksperimen sebesar 4,607 dengan $\mathrm{dk}=4$ dan pada kelas kontrol $\chi^{2}{ }_{\text {hitung }}$ sebesar 2,608 dengan $\mathrm{dk}=4$. Hal ini menunjukkan bahwa data hasil belajar fisika siswa untuk kedua kelas terdistribusi normal. Uji hipotesis yang digunakan yaitu uji statistik parametrik dengan persamaan uji-t polled varians. Hasil uji hipotesis dapat dilihat pada Tabel 3 berikut.

Tabel 3. Hasil Analisis Uji Hipotesis Hasil Belajar Fisika Peserta didik

\begin{tabular}{llllll}
\hline Kelas & Jumlah Peserta Didik (n) & Rata-rata & Varians $\left(\mathrm{s}^{2}\right)$ & $t_{\text {hitung }}$ & $t_{\text {tabel }}$ \\
\hline Eksperimen & 21 & 80,57 & 58,0572 & 2,163 & 1,685 \\
Kontrol & 20 & 75,6 & 50,3579 & & \\
\hline
\end{tabular}

Berdasarkan Tabel 3 di atas, terlihat bahwa nilai $t_{\text {hitung }}$ lebih besar dibandingkan dengan $t_{\text {tabel }}$ yaitu 2,163 > 1,685 pada taraf signifikasi 5\% dengan derajat kebebasan ( $\mathrm{dk}$ ) sebesar 39 sehingga $\mathrm{H}_{0}$ dapat ditolak. Artinya, terdapat perbedaan hasil belajar peserta didik pada kelas eksperimen dan kelas kontrol. Dengan demikian, dapat dikatakan bahwa terdapat pengaruh model guided inquiry learning terhadap hasil belajar siswa.

Sebelum diberikan perlakuan, dilakukan tes awal terlebih dahulu untuk mengetahui kemampuan awal siswa dari kedua sampel. Data hasil tes awal menunjukkan bahwa nilai rata-rata siswa pada kelas eksperimen sebesar 30,10 dan kelas kontrol sebesar 33,20. Berdasarkan uji homogenitas dan uji normalitas dari data tes awal hasil belajar, didapatkan bahwa kedua kelas homogen dan terdistribusi normal. Setelah mengetahui homogenitas dan normalitas sebaran data awal, kemudian kedua kelas diberi perlakuan. Kedua kelas diberikan perlakuan selama tiga kali pertemuan dengan alokasi waktu selama 90 menit (2 jam pelajaran). Perlakuan yang diberikan kepada kelas eksperimen adalah penggunaan alat laboratorium dengan model guided inquiry learning dengan materi besaran dan pengukuran, sedangkan kelas kontrol menggunakan pembelajaran konvensional dengan materi yang sama. Menurut Huda, dkk (2019), penggunaan alat laboratorium berupa alat peraga dapat meningkatkan penguasaan konsep dan kemampuan pemecahan masalah fisika siswa di SMA.

Sebelum melakukan uji-t pada hasil kemampuan akhir, dilakukan terlebih dahulu uji homogenitas dan uji normalitas data hasil tes akhir. Berdasarkan hasil uji homogenitas dan uji normalitas data hasil akhir didapatkan bahwa kedua kelas homogen dan terdisribusi normal. Selanjutnya dilakukan uji hipotesis dengan menggunakan uji statistik (uji-t polled varian), diperoleh nilai $t_{\text {hitung }}$ lebih besar dari $t_{\text {tabel }}$ dengan harga $t_{\text {hitung }}=2,163 ; t_{\text {tabel }}=2.023$. Hal ini menunjukkan bahwa terdapat pengaruh model guided inquiry learning terhadap hasil belajar siswa pada kelas eksperimen dengan kelas kontrol yang menggunakan pembelajaran langsung atau pembelajaran konvensional. Menurut Suprijono (2013), hasil belajar adalah pola perubahan, nilai-nilai, pengertian-pengertian, sikap-sikap, apresiasi dan keterampilan.

Hasil penelitian tersebut di atas menunjukkan bahwa kemampuan akhir hasil belajar siswa berbeda dengan kemampuan awal. Kelas eksperimen maupun kelas kontrol mengalami peningkatan, namun peningkatan hasil belajar siswa pada kelas eksperimen lebih tinggi dibandingkan dengan kelas kontrol. Beberapa faktor yang mempengaruhi hasil penelitian ini adalah pada kelas eksperimen menggunakan alat laboratorium, dengan adanya pembelajaran menggunakan alat laboratorium dan 
model guided inquiry learning, siswa menjadi lebih antusias dalam mengikuti proses pembelajaran fisika. Langkah-langkah model guided inquiry learning dalam penelitian ini terdiri dari 6 langkah seperti dijelaskan dalam Trianto (2007) yakni menyajikan pertanyaan atau masalah, membuat hipotesis, merancang percobaan, melakukan percobaan untuk memperoleh informasi, mengumpulkan dan menganalisis data, dan membuat kesimpulan. Kurniawati, et.al (2014) menyatakan bahwa guided inquiry learning dapat mengembangkan cara berfikir ilmiah yang menempatkan siswa sebagai pembelajar dalam memecahkan permasalahan dan memperoleh pengetahuan yang bersifat penyelidikan sehingga dapat memahami konsep-konsep sains. Model guided inquiry learning mampu mengembangkan keinginan dan motivasi siswa untuk mempelajari prinsip-prinsip dan konsep-konsep dalam pembelajaran. Selain itu, model guided inquiry learning ini memberikan kesempatan dan pengalaman belajar siswa sehingga dapat membantu siswa untuk mengonstruksi konsep yang dipelajari.

\section{KESIMPULAN}

Kesimpulan penelitian ini adalah terdapat pengaruh model guided inquiry learning terhadap hasil belajar siswa di SMAN 1 Pringgarata.

\section{SARAN}

Saran yang dapat penulis berikan adalah sebagai berikut: Alat laboratorium adalah media pembelajaran yang dapat dipakai oleh guru dalam meningkatkan hasil belajar fisika siswa di SMA. Penggunaan alat laboratorium dalam proses pembelajaran dapat diterapkan oleh guru dengan tujuan untuk meningkatkan minat belajar siswa. Penggunaan alat laboratorium pada pembelajaran, khususnya fisika sangatlah disarankan, sebab dengan adanya suatu praktikum atau kegiatan percobaan akan membantu siswa lebih tahu konsep-konsep dan hukum fisika itu sendiri.

\section{UCAPAN TERIMAKASIH}

Penelitian ini tidak menerima hibah khusus dari agensi pendanaan mana pun di sektor publik, komersial, atau nirlaba.

\section{DAFTAR PUSTAKA}

Anam, K. (2015). Pembelajaran Berbasis Inkuiri Metode dan Aplikasi. Yogyakarta: Pustaka Pelajar.

Arikunto, S. (2013). Manajemen Penelitian. Jakarta: PT. Rineka Cipta.

Hayati SN., Hikmawati, Wahyudi. (2017). Pengaruh Model Pembelajaran Inkuiri dengan Menggunakan Media Simulasi Terhadap Hasil Belajar Fisika Siswa Kelas X MIA SMAN 1 Lingsar Lombok Barat Tahun Pelajaran 2016/2017. Jurnal Pendidikan Fisika dan Teknologi, III (1), 48-54.

Huda N, Hikmawati, Kosim. (2019). Pengaruh Pendekatan Kontekstual Berbantuan Alat Peraga Terhadap Penguasaan Konsep Dan Kemampuan Pemecahan Masalah Fisika. J. Pijar MIPA, 14 (1), 62 - 72.

Kurniawati, I.D., Wartono \& Diantoro, M. (2014). Pengaruh Pembelajaran Inkuiri Terbimbing Integrasi Peer Instruction Terhadap Penguasaan Konsep dan Kemampuan Berfikir Kritis Siswa. Jurnal Pendidikan Fisika Indonesia, 10, 36-46.

Riduwan. (2014). Dasar-Dasar Statistika. Bandung: Alfabeta. 
Shoimin, A. (2016). 68 Model Pembelajaran Inovatif dalam Kurikulum 2013. Yogyakarta: ArRuzz Media.

Sugiyono. (2013). Metode Penelitian Pendidikan Pendekatan Kuantitatif, Kualititatif, dan R $\mathcal{E}$ D. Bandung: Alfabeta.

Sugiyono. (2012). Statistika Untuk Penelitian. Bandung: Alfabeta.

Suprijono, A. (2010). Cooperative Learning Teori dan Aplikasi PAIKEM. Yogyakarta: Pustaka Pelajar.

Susilawati, Susilawati \& Sridana, N. (2015). Pengaruh Model Pembelajaran Inkuiri Terbimbing Terhadap Keterampilan Proses Sains Siswa. Jurnal Tadris IPA Biologi FITK IAIN Mataram. 3(1), 23-36.

Trianto. (2010). Mendesain Model Pembelajaran Inovatif-Progresif. Jakarta: Kencana.

Trianto. (2007). Model-model Pembelajaran Inovatif Berorientasi Konstruktivistik. Jakarta: Perpustakaan Nasional.

Wahyuni R., Hikmawati, Taufik M. (2016). Pengaruh Model Pembelajaran Inkuiri Terbimbing dengan Metode Eksperimen terhadap Hasil Belajar Fisika Siswa Kelas XI IPA SMAN 2 Mataram Tahun Pelajaran 2016/2017. Jurnal Pendidikan Fisika dan Teknologi. II (4), 164-169. 